\title{
Analysis of the Influence of Product Quality and Promotion of Consumer Decisions to Subscribe to Mnc Vision (Case Study at pt. Mnc Sky Vision Palembang)
}

\author{
Amrulah Robi, Zakaria Wahab, Marlina Widiyanti
}

\begin{abstract}
This study aims to look at consumer decisions in subscribing to MNC Vision at PT. MNC Sky Vision Palembang with independent variables of quality research and promotion. The study population was 540 MNC Vision customers in Palembang in 2018. As for the sample, there were 100 customers at the MNC Vision Palembang. This study uses the research method of multiple linear regression analysis. Based on the test results it was found that there was a positive and significant influence on the quality and promotion of consumer decisions in influencing consumer decisions to subscribe to MNC Vision.
\end{abstract}

Keywords: Quality Product, Promotion, Decisions of Consumer

\section{INTRODUCTION}

PT MNC Sky Vision Tbk as a TV subscription pioneer in Indonesia has proved its existence for more than 23 years in providing the best service for the people of Indonesia. In 2017, the condition of the subscription TV industry is increasingly dynamic with increasing competition and innovation. The Company considers the tight competition as a challenge to continuously improve the quality of services provided, in accordance with the Company's commitment to provide the best quality entertainment, the most complete channels and world-class quality shows that entertain and educate the nation. In 2017, the company made a big transformation by combining the Indovision brand, Oke Vision and Top TV to become MNC Vision. This changes was carried out without eliminating the best features previously used such as the use of Indostar-II satellites and S-band frequencies. The latest features such as Multi Decoder, High Definition, MNC Vision Plus and Super Bundle are also presented to bring customers to a higher level of subscription TV services. Instead of the Company added the number of channels to 137 channels with 23 exclusive in-house channels. Along with these changes, the Company as one of the best subscription TV in Indonesia is moving

Revised Manuscript Received on August 14, 2019.

* Correspondence Author

Amrulah Robi*, Corresponding Author, Candidate Master of Management in Magister Management University of Sriwijaya, Indonesia.

Dr. Zakaria Wahab, M.B.A, Lectures in Faculty Economic University of Sriwijaya, Indonesia.

Hj. Marlina Widiyanti, S.E., S.H., M.M., Ph.D., Lectures in Faculty Economic University of Sriwijaya, Indonesia.

(C) The Authors. Published by Blue Eyes Intelligence Engineering and Sciences Publication (BEIESP). This is an open access article under the CC BY-NC-ND license (http://creativecommons.org/licenses/by-nc-nd/4.0/) towards a new vision to provide experience to customers using exceptional subscription TV services. MNC Vision Palembang, is one of the branch offices of MNC Vision company. In order to manifest the company's vision and mission, MNC Vision Palembang is committed to exist continously in meeting the needs of consumers, especially in the city of Palembang. With 23 years of experience in the subscription TV business, the Company believes the presence of MNC Vision in Palembang is able to answer the needs of consumers in the city of Palembang not only in providing quality shows, but also in providing better and more qualified educational, informative and entertaining shows for the community especially in the city of Palembang. The following are in Table 1.1 MNC Vision Palembang customer data (Excisting):

Table 1. Data on Palembang MNC Vision Customers (Active)

\begin{tabular}{lccc}
$\begin{array}{l}\text { Data of } \\
\text { Customer }\end{array}$ & $\mathbf{2 0 1 8}$ & $\mathbf{2 0 1 7}$ & $\mathbf{2 0 1 6}$ \\
\hline $\begin{array}{l}\text { Number of } \\
\text { Customers }\end{array}$ & 540 & 685 & 450 \\
Difference & 145 & 235 & 0 \\
\hline Percentage & $\mathbf{( - )} \mathbf{2 6 , 8 5 \%}$ & $\mathbf{( + )} \mathbf{3 4 , 3 1}$ & $\mathbf{0 , 0 0 \%}$ \\
\hline
\end{tabular}

Source: MNC SKY Vision Palembang

Based on Table 1, MNC Vision Palembang customer data shows the development of the active number of MNC Vision customers in Palembang since 2016 - 2018. In the above data it can be seen that the increase in the number of MNC Vision customers in 2017 has risen (30\%) from the previous period. But then there was a significant decline in the 2018 period amounting to (26.85\%). The decrease in the number of customers is one of the effects of the tight - competition that occurs especially in the subscription TV business that has been mentioned earlier. The following are the results of TV surveys Subscribe to Halomoney's best Indonesian version: 
Analysis of the Influence of Product Quality and Promotion of Consumer Decisions to Subscribe to Mnc Vision (Case Study at pt. Mnc Sky Vision Palembang)

Table 4. Promotion Activities of Palembang MNC Vision

\begin{tabular}{|ccc}
\hline $\mathbf{N}$ & $\begin{array}{r}\text { Type of } \\
\text { o. }\end{array}$ & Information \\
\hline 1 & Advertising & \\
\hline
\end{tabular}

Radio Promotion through advertising on

Advertising radio in the city of Palembang

Table 2. The Best Results of Subscribed TV Surveys in Indonesia by Customer-HaloMoney.co.id

\begin{tabular}{ccc}
\hline No. & Subscription TV & Rating \\
\hline 1 & Centrin TV & 11 \\
2 & My Republic & 10 \\
3 & NexMedia & 9 \\
4 & Aora TV & 8 \\
5 & Orange TV & 7 \\
6 & K-Vision & 6 \\
7 & Trans Vision & 5 \\
8 & Big TV & 4 \\
9 & First Media & 3 \\
10 & MNC Sky Vision & 2 \\
11 & Indihome & 1 \\
\hline
\end{tabular}

Source: MNC SKY Vision Palembang

Based on the data in Table 2, it can be seen that currently Indihome is the first rank of best subscription TV in Indonesia. Furthermore, followed by the 2nd rank is occupied by MNC Sky Vision and 3rd place is First Media. Indihome's dominance is caused nowadays instead of needing their subscription TV, they also need an Internet network. The development of internet technology such as fiber technology and 4G networks can support and encourage purchasing decisions by consumers to choose subscription TV services that are compatible with today's lifestyle. To accommodate customer interest and encourage penetration level growth so as to encourage consumer purchasing decisions in meeting their needs, the Company has applied these two technologies into one of MNC Vision's services as a successful subscription TV in anticipation of increasingly intense competition between subscription TV.

Table 3. List of TV Service Products Subscribed to MNC Vision

\begin{tabular}{ccc}
\hline No. & Package Type & $\begin{array}{c}\text { Number of } \\
\text { Channels }\end{array}$ \\
\hline 1 & Silver & 52 \\
2 & Gold & 72 \\
3 & Venus & 77 \\
4 & Galaxy & 92 \\
5 & Super Galaxy & 98 \\
\hline Source: MNC SKY Vision Palembang
\end{tabular}

In service industries such as subscription TV, companies are always required to offer quality products that has more value, so that they look differently from other competiting products. On the Silver package type MNC Vision offers quality TV subscription packages especially for children, with protecting channel TV for consumers as parents so that they can freely control children's shows and provide more educative education to children who enjoy impressions with the choice of Silver packages offered. Furthermore, for the Venus, Galaxy, Super Galaxy, MNC Vision package groups channels that focus on information media such as non-stop 24-hour local and international news shows for customers who are actively following the development of the world business that is more creative. And finally the Gold MNC Vision package is specifically for customers who prefer entertainment shows such as cinema films and TV Series shows. Lastly on the MNC Vision Gold package specifically for customers who prefer entertainment shows such as theater films and TV Series shows. Consumers can enjoy the shows that seem to have a mini cinema in a private home.
TV

advertisement Policy)

Social media Marketing ads through social media like Facebook and Instagram

2 Sales

Promotion

6 Month

Package

1 year package Pay 9 months Free 3 months, 4 months all channel, Free of charge

Socialization Promotions carried out routinely at certain events held in the city of Palembang

3 Direct

Marketing

(Pemasaran

Langsung)

Pay 5 months Free 1 month, 2 months all channel, Free of charge

Source: MNC SKY Vision Palembang

\section{LITERATURE REVIEW}

\section{A. Quality of Product}

Product quality is one factor in marketing, because of the quality of products that can be trusted to show its function.

\section{B. Promotion}

Promotion is a form of communication between marketing activities by disseminating information, influencing or reminding the market to accept, buy and be loyal to the products offered by the company offered.

\section{Buying decision}

Buying decisions are the stage where consumers have choices and are ready to buy ownership rights or use of goods and services.

\section{Relationship Between Variables and Development of Hypotheses}

1. Effect of Product Quality (X1) on Consumer Decisions (Y)

Product quality is closely related to purchasing decisions, where product quality is one aspect of consumer consideration in deciding purchases. Good product quality will lead to customers satisfaction which will further make consumers loyal to the product.

Companies must be able to provide quality in accordance with the wishes and needs of consumers by paying attention to existing market quality standards. This gives a reason that the quality provided by the company is no less competitive than its competitors. 
H1 : Product Quality has a positive and significant effect on Purchasing Decisions

\section{Effect of Promotion (X2) on Consumer Decisions (Y)}

Promotion is an important influence in making purchasing decisions. Promotion is one of the marketing variables that can be used by consumers as a reference in choosing the desired goods or services. The relationship between promotion and purchasing decisions is one way of introducing, communicating the benefits of a product or service that invites consumers to use products / services that are promoted will lead to market demand. Conversely, if the consumer has never heard and not sure about the product / service being promoted, it will not create demand. Promotion also determines the success of the company in a good marketing program that is treated as a strategy development framework to form an effective marketing strategy so that the company can penetrate the intended market so that it can achieve the predetermined sales targets.

H2 : Promotion has a positive and significant effect on Purchasing Decisions

\section{E. Conceptual Framework for Thought}

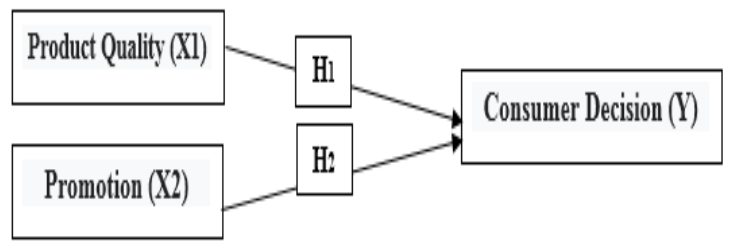

\section{RESEARCH METHODS}

Based on data of the number of customers in 2018, the total population in this study was 540 active MNC Vision customers in Palembang. Then the sample to be used in this study is 84.37 which is rounded up to 100 respondents who are active customers of the Palembang MNC Vision.

\section{RESULTS AND DISCUSSION}

\section{A. Research result}

Table 4. Profile of Research Respondents by Package of Products Used

\begin{tabular}{|c|c|c|c|}
\hline No & $\begin{array}{c}\text { Package of } \\
\text { Products } \\
\text { Used }\end{array}$ & $\begin{array}{l}\text { Frequency } \\
\text { (Person) }\end{array}$ & $\begin{array}{l}\text { Percentage } \\
(\%)\end{array}$ \\
\hline 1 & Silver & 14 & 14 \\
\hline 2 & Gold & 19 & 19 \\
\hline 3 & Venus & 31 & 31 \\
\hline 4 & Galaxy & 14 & 14 \\
\hline 5 & $\begin{array}{l}\text { Super } \\
\text { Galaxy }\end{array}$ & 22 & 22 \\
\hline \multicolumn{2}{|r|}{ Total } & 100 & 100 \\
\hline
\end{tabular}

Based on Table 4, it can be seen that the product package used by the respondents with the most or the majority is the Super Galaxy product package with $22 \%$, while the minority packages of products used are Silver and Galaxy with $14 \%$ each.
Test of Reliability

\begin{tabular}{lcccc}
\hline \multicolumn{1}{c}{ Variable } & $\begin{array}{c}\text { Cronbach's } \\
\text { Alpha }\end{array}$ & $\begin{array}{c}\text { Cutt } \\
\text { Off }\end{array}$ & $\begin{array}{c}\text { N of } \\
\text { Item }\end{array}$ & Inform. \\
\hline $\begin{array}{l}\text { Quality of } \\
\text { Product (X1) }\end{array}$ & 0,752 & $>$ & 10 & Reliable \\
$\begin{array}{l}\text { Promotion } \\
\text { (X2) }\end{array}$ & 0,722 & 0,60 & & \\
Consumer & 0,691 & $>, 60$ & 10 & Reliable \\
Decisions (Y) & & 0,60 & 10 & Reliable \\
\hline
\end{tabular}

Test of Simultan (F test)

\begin{tabular}{|c|c|c|c|c|c|c|}
\hline \multicolumn{7}{|c|}{ ANNOVA $^{\mathrm{b}}$} \\
\hline Model & & $\begin{array}{l}\text { Sum of } \\
\text { Squares }\end{array}$ & $\mathrm{Df}$ & $\begin{array}{c}\text { Mean } \\
\text { Square }\end{array}$ & $\mathbf{F}$ & Sig. \\
\hline \multirow[t]{3}{*}{1} & Regres. & 149.441 & 2 & 74.721 & 16.009 & $.000^{\mathrm{a}}$ \\
\hline & Residual & 452.749 & 97 & 4.668 & & \\
\hline & Total & 602.190 & 99 & & & \\
\hline \multicolumn{7}{|c|}{ Unbound Variables: Product Quality and Promotion } \\
\hline \multicolumn{7}{|c|}{ Bound Variables: Purchase Decisions } \\
\hline
\end{tabular}

Test of Individual Parameter Significance (t Test)

\begin{tabular}{|c|c|c|c|c|c|c|}
\hline \multicolumn{7}{|c|}{ Coefficients } \\
\hline Model & & \multicolumn{2}{|c|}{$\begin{array}{c}\text { Unstandardized } \\
\text { Coefficients }\end{array}$} & \multirow{2}{*}{$\begin{array}{c}\begin{array}{c}\text { Standardized } \\
\text { Coefficients }\end{array} \\
\text { Beta }\end{array}$} & \multirow[t]{2}{*}{$\mathbf{t}$} & \multirow[t]{2}{*}{ Sig. } \\
\hline 1 & & B & $\begin{array}{l}\text { Std. } \\
\text { Error }\end{array}$ & & & \\
\hline & (Constant) & 10.315 & 1.775 & & 5.811 & 0,000 \\
\hline & $\begin{array}{l}\text { Quality } \\
\text { Product }\end{array}$ & 0,194 & 0,077 & 0,229 & 2.516 & 0,014 \\
\hline & Promotion & 0,335 & 0,078 & 0,389 & 4.278 & 0,000 \\
\hline
\end{tabular}

\section{B. Discussion of Research Results}

1. Effect of Product Quality (X1) on Consumer Decisions (Y)

The quality of the products provided by MNC Vision has been very good. However, companies need to improve product quality such as image and audio quality. Several times more often occur in audio quality and images that are still unclear, therefore MNC Vision companies need to improve image and audio quality to be even better so that consumers trust MNC Vision's product quality better than its competitors.

2. Effect of Promotion (X2) on Consumer Decisions (Y)

Promotion also determines the success of the company in a good marketing program that is treated as a strategy development framework to form an effective marketing strategy so that the company can penetrate the intended market so that it can achieve the predetermined sales targets.

\section{Research Implications Theoretical implications}

This research is expected to increase understanding for academics related to theories regarding purchasing decisions. So that the results of this study can be added as new insights for academics in addition to existing theories. This research is also expected to be a foundation or material to be developed again and tested with different phenomena or objects so that it is expected to be able to provide diversity and enrich the theory through different objects in the world of marketing. 


\section{Practical implications}

The results of this study can provide information that is very useful for practitioners to know the factors that influence the process of consumer purchasing decisions. The results of this study also show how the marketing concepts of product quality and successful promotions are applied by MNC Vision companies. This research can also be used as input in formulating marketing strategies and decision making related to product quality and promotion and can provide a view for marketing managers in developing strategies to market their products effectively and efficiently.

\section{CONCLUSION}

Product quality variables and Promotion variables have a positive and significant effect on purchasing decisions at MNC Vision in Palembang.

\section{SUGGESTION}

\section{For MNC Vision Parties}

a. The promotion carried out by MNC Vision has been very good. But what needs to be improved is by making more interesting promotions so that consumers are interested in making purchases and subscribing using MNC Vision. Besides that, the promotion that needs to be done is by getting involved in events that are often carried out to attract consumer interest.

b. Product quality provided by the seller (seller) is good. But what needs to be improved is the image and audio quality provided by MNC Vision needs to be improved by making the results of the images and audio better and not broken so that consumers are more interested in using TV subscription from MNC Vision.

\section{Research Limitations}

This research has limitations that can be used as consideration for the next researcher to get better results. This study still has several limitations which include:

1. The sample used in this study was only obtained from MNC Vision consumers in purchasing decisions which included the category of MNC Vision subscription TV customers. So the results in this study are still relatively low genaralization.

2. In this research there are two independent variables namely product quality and promotion. But actually there are still other variables that have a relationship to the behavior of consumer purchasing decisions that are not listed in this study.

\section{REFERENCES}

1. Achmad J., Zainul A., Kadarismasn. 2015. Pengaruh Promosi Online dan Persepsi Harga Terhadap Keputusan Pembelian (Survei Pada Pelanggan Aryka Shop di Kota Malang). Jurnal Administrasi Bisnis (JAB). Vol. 21 No. 1 April 201. Universitas Brawijaya.

2. Andrew F. M., Irvan. 2016. Pengaruh Produk, Harga, Promosi dan Tempat Terhadap Keputusan Pembelian Mobil di PT. Astra International, Tbk Malalayang. Jurnal EMBA. Vol.4 No.1 Maret 2016, Hal. 472-483. ISSN 2303-1174.

3. Arianto S., Imroatul. 2016. Analisis Pengaruh Persepsi Harga, Kualitas Pelayanan, Promosi dan Lokasi Terhadap Keputusan Pembelian (Studi pada Floo Cafe Ungaran). Diponegoro Journal of Management. Volume 5, Nomor 4, Tahun 2016, Halaman 1-14. ISSN (Online): 2337-3792.

4. Arif R. N., Rizal. 2017. Pengaruh Promosi, Harga, dan Kualitas Pelayanan Terhadap Keputusan Pembelian (Studi Pada Rahma Rahmi Collection). Diponegoro Journal of Management. Volume 6, Nomor 4, Tahun 2017, Halaman 1 - 9. ISSN (Online): 2337-3792.
5. Arum Y., Susilo. 2016. Analisis Pengaruh Citra Merek, Produk, Harga dan Promosi Terhadap Keputusan Pembelian (Studi pada Konsumen Bandeng Juwana Elrina). Diponegoro Journal of Management. Volume 5, Nomor 3, Tahun 2016, Halaman 1-11. ISSN (Online): 2337-3792.

6. Christy J. G., Jantje S., Sjendry. 2017. Pengaruh Kualitas Produk, Harga dan Promosi Terhadap Keputusan Pembelian Mobil Nissan X-Trail pada PT. Wahana Wirawan Manado. Jurnal EMBA. Vol.5 No.2 Juni 2017, Hal. 2221 - 2229. ISSN 2303-1174.

7. Danang, Sunyoto. 2013. Metodologi Penelitian Akuntansi. Bandung: PT. Refika Aditama Anggota Ikapi.

8. Daniel O. R., Azis F., Leonardo. 2015. Pengaruh Kualitas Pelayanan, Harga dan Promosi Terhadap Keputusan Pembelian Produk CKE Teknik Semarang. Jurnal Universitas Diponegoro.

9. Ghozali, Imam. 2013. Aplikasi Multivariate dengan Program SPSS. Edisi Ketujuh. Semarang: Badan Penerbit Universitas Diponegoro.

10. Giardo P. P., Zainul A., Sunarti. 2017. Pengaruh Kualitas Produk Terhadap Keputusan Pembelian dan Dampaknya Terhadap Kepuasan Konsumen (Survei pada Mahasiswa Administrasi Bisnis Fakultas Ilmu Administrasi angkatan 2013 dan 2014 Universitas Brawijaya yang Melakukan Pembelian Paket Data Kampus). Jurnal Administrasi Bisnis (JAB). Vol. 48 No.1 Juli 2017. Universitas Brawijaya.

11. Indra K., Zakaria W., Welly. 2016. Pengaruh Brand Image dan Kualitas Produk Terhadap Keputusan Pembelian Produk Pizza Hut di Kota Palembang. Jurnal Ilmiah Manajemen Bisnis Dan Terapan. Tahun XIII No 1, April 2016. Universitas Sriwijaya.

12. Jilly Bernadette Mandey. 2013. Promosi, Distribusi, Harga Pengaruhnya Terhadap Keputusan Pembelian Rokok Surya Promild. Jurnal EMBA. Vol.1 No.4 Desember 2013, Hal. 95-104. ISSN 2303-1174

13. Kotler dan Keller. 2012. Manajemen Pemasaran. Edisi 12. Jakarta: Erlangga.

14. Kotler, Philip, Armstrong, Gary. 2014. Prinsip-prinsip Manajemen Edisi 14, Jilid 1. Jakarta: Erlangga.

15. Krestiawan W. S., Handoyo D. W., Sari. 2013. Pengaruh Kualitas Produk, Harga, dan Promosi Terhadap Keputusan Pembelian Permen Tolak Angin di Semarang (Studi Kasus pada Pengguna Permen Tolak Angin di Kelurahan Tembalang Semarang). Diponegoro Journal of Social and Politic. Tahun 2013, Hal. 1-10.

16. Lidya M., Lisbeth M., Agusta. 2013. Kualitas Produk, Strategi Promosi dan Harga Pengaruhnya Terhadap Keputusan Pembelian Kartu Simpati Telkomsel di Kota Manado. Jurnal EMBA. Vol.1 No.4 Desember 2013, Hal. 2336-2346. ISSN 2303-1174.

17. Melita Y., Agustin. 2016. Analisis Kualitas Produk, Harga dan Promosi Terhadap Keputusan Pembelian Motor Honda Vario (Studi Kasus Pada Tridjaya Motor Dealer Resmi Motor Honda Cabang Girian-Bitung). Jurnal Berkala Ilmiah Efisiensi. Volume 16 No. 03 Tahun 2016.

18. Milly L., Mokoagouw. 2016. Pengaruh Gaya Hidup, Harga, Kualitas Produk Terhadap Keputusan Pembelian Handphone Samsung di Samsung Mobile IT Center Manado. Jurnal Berkala Ilmiah Efisiensi. Volume 16 No. 01 Tahun 2016.

19. Mudrajat, Kuncoro. 2013. Manajemen Riset untuk Bisnis dan Ekonomi. Edisi 4. Jakarta: Erlangga.

20. Muhammad A., Imroatul. 2017. Analisis Pengaruh Kualitas Produk, Persepsi Harga dan Sikap Terhadap Keputusan Pembelian (Studi pada Pos Ketan Legenda 1967 Kota Semarang). Diponegoro Journal of Management. Volume 6, Nomor 4, Tahun 2017, Halaman 1-11. ISSN (Online): 2337-3792.

21. Novi A., Purba. 2016. Pengaruh Bauran Pemasaran (Kualitas Produk, Harga, Promosi dan Saluran Distribusi) Terhadap Keputusan Pembelian Yamaha NMAX di Semarang. Jurnal Universitas Diponegoro.

22. Putri R. P., Agus. S. S., Ferdy. 2018. Pengaruh Promosi dan Word of Mouth Terhadap Keputusan Pembelian di Oriflame Manado. Jurnal EMBA. Vol.6 No.4 September 2018, Hal. 3703 - 3712. ISSN 2303-1174.

23. Rendy C. A., Muchsin Saggaf. 2016. Membangun Kualitas Layanan, Kualitas Produk dan Persepsi Harga Untuk Mendukung Word of Mouth Melalui Kepuasan. Jurnal Manajemen dan Bisnis Sriwijaya. Vol. 14 No. 1 Maret 2016.

24. Rindang L. S., Silvya L. M., Agus. 2014. Citra Merek, Harga dan Promosi Pengaruhnya Terhadap Keputusan Pembelian Perhiasan Emas Pada PT. Pegadaian (Persero) Cabang Manado Utara. Jurnal EMBA. Vol.2 No.2 Juni 2014, Hal. 1222-1232. ISSN 2303-1174.

Published By: \& Sciences Publication (C) Copyright: All rights reserved.

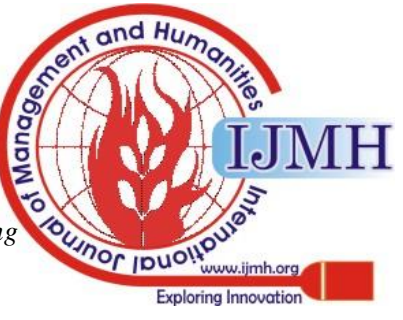


25. Rizki S. H., Sutopo. 2016. Analisis Pengaruh Persepsi Harga dan Promosi Terhadap Keputusan Pembelian Konsumen (Studi Kasus pada Warung Spesial Bebek Goreng Andalan). Diponegoro Journal of Management. Volume 5, Nomor 3, Tahun 2016, Halaman 1-10. ISSN (Online): 2337-3792.

26. Sandy S., Irvan. 2015. Pengaruh Harga, Lokasi, Promosi dan Kualitas Layanan Terhadap Keputusan Pembelian Pada Toko Komputer Game Zone Mega Mall Manado. Jurnal EMBA. Vol.3 No.3 Sept. 2015, Hal.300-311. ISSN 2303-11.

27. Selvie N., Silvya. L. M., Lotje. 2017. Pengaruh Promosi, Harga, Dan Distribusi Terhadap Keputusan Pembelian Pakaian Pada Matahari Departemen Store Manado (Studi Kasus Di Matahari Departemen Store Manado Town Square). Jurnal EMBA. Vol.3 No.2 Juni 2017, Hal. 2221 - 2229. ISSN 2303-1174.

28. Selvany C. L., Joyce L., Silcyljeova. 2015. Pengaruh Kualitas Produk, Harga dan WOM (Word of Mouth) Terhadap Keputusan Pembelian Handphone Evercross Pada CV. Tristar Jaya Globalindo Manado. Jurnal EMBA. Vol.3 No.3 Sept. 2015, Hal.817-826. ISSN 2303-11.

29. Sugiyono. 2012. Metode Penelitian Administrasi, Bandung: CV. Alfabeta.

30. Tjiptono, Fandy, Gregorius. 2012. Pemasaran Strategik. Yogyakarta: Andi.

31. Triastuti A., Handoyo. 2017. Pengaruh Kualitas Produk, Citra Merek dan Iklan Terhadap Keputusan Pembelian Kartu XL Prabayar di Kota Semarang (Studi Kasus pada Pengguna Kartu XL Prabayar di Kota Semarang). Diponegoro Journal of Social and Political. Tahun 2017 Hal 1-6.

32. Vania S., Silvya L. M., Silcyljeova. 2019. Pengaruh Lokasi, Promosi dan Persepsi Harga Terhadap Keputusan Pembelian Konsumen Pada Perumahan Kawanua Emerald City Manado. Jurnal EMBA. Vol.7 No.1 Januari 2019, Hal. 881 - 890. ISSN 2303-1174.

33. Wanda S. P., Bernhard T., Hendra. 2017. Analisis Pengaruh Persepsi Harga, Produk, Promosi dan Tempat Terhadap Keputusan Pembelian Sepeda Motor Yamaha Vixion (Studi Kasus Pada Konsumen Pengguna Amurang). Jurnal EMBA. Vol.5 No.2 Juni 2017, Hal. 2221 2229. ISSN 2303-1174.

\section{AUTHORS PROFILE}

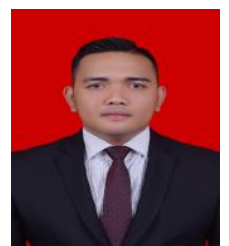

Amrulah Robi, Corresponding Author, Candidate Master of Management in Magister Management University of Sriwijaya, Indonesia.

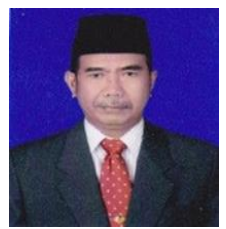

Dr. Zakaria Wahab, M.B.A, Lectures in Faculty Economic University of Sriwijaya, Indonesia.

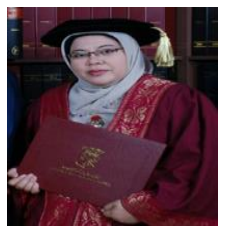

Hj. Marlina Widiyanti, S.E., S.H., M.M., Ph.D., Lectures in Faculty Economic University of Sriwijaya, Indonesia.

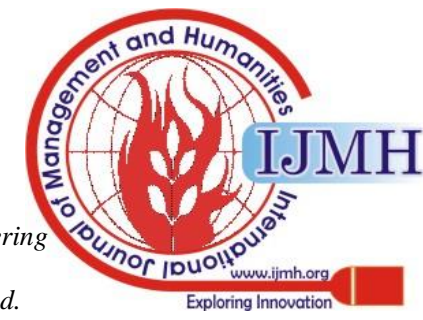

